FILOZOFIA

Roč. 75,2020 , č. 1

DOI: https://doi.org/10.31577/filozofia.2020.75.1.3

\title{
BÉLA HAMVAS'S CONCEPT OF AUTHENTIC TRADITION IN EUROPEAN CONTEXT
}

BÉLA MESTER, Institute of Philosophy of the Research Centre for the Humanities, Budapest, Hungary

\author{
MESTER, B.: Béla Hamvas's Concept of Authentic Tradition in European \\ Context \\ FILOZOFIA, 75, 2020, No 1, pp. 28 - 39
}

\begin{abstract}
A basic element of Béla Hamvas's philosophy of crisis is an experiment for the reconstruction of the authentic tradition. Hamvas's concept of tradition has significant parallelism with Karl Jaspers' theory of axial age. This paper offers an analysis of the parallelism between Hamvas's ideas about the sacred books as fragments of the unwritten ancestral tradition of the humankind and Jaspers' theory about the foundations of the unity of humankind in the works written in the axial age. Assmann's theory of cultural memory will be used in the present writing as a theoretical frame of this comparison. By the hypothesis of this paper, a common element in the topics of German and Hungarian thinkers is the transition of the cultural memory from the ritual to the textual coherence, clarified by Assmann's theory. In the last part of this paper it will be exemplified that Hamvas's endeavour for the canonisation of the unwritten ancestral tradition in written form by his commented edition of Confucius' Lunyu.
\end{abstract}

Keywords: Ancestral tradition - Axial age - Canonisation - Cultural memory Ritual coherence - Textual coherence

\section{Introduction}

However, the œuvre of Béla Hamvas (*1897, Prešov; grew up in Bratislava; $† 1968$, Budapest) and its reception creates serious separate libraries, (for the most complete monography see Darabos 2002); in the following just a single fundamental term will be discussed namely tradition, what is inseparable from another keyword of the œuvre, crisis. In his opinion, tradition is an eternal antidote to the perpetual crisis of the human existence; the term crisis used in a larger meaning than the whole of the economic, political, and military crises, in his works. Humans can reach the sphere of the authenticity starting from that of the inauthenticity, the realm of the existence starting from that of the pure life, by other words, the timeless golden age starting from the apocalypse of the present; by touching the tradition personally and actively, not by a mere intellectual reconstruction. After an overview of the loci for the interpretations of the tradition in his œuvre; one can observe a specific duality. When he refers generally to the tradition, the emphasis is on its timeless, everlasting and changeless nature and on its unity for the whole humankind; by other ways the numerous and 
highly different texts, offered by him as mediators of a timeless tradition must be dissolved in a particular context of their history and culture when they have been interpreted. Any historical or cultural determination of a text as a mediator of the tradition was contrary to the doctrine about the changeless nature and the unity for the whole humankind of the tradition. In other loci of the œuvre is clear that the crisis is not the pure, timeless crisis of our individual existences, it has connections with the actual state of the world, and with the epoch of the lifetime of the author, as well. However, tradition is a reactivated ancestral knowledge of the humankind in us for the solution of the timeless crisis; its concretely visible face is a text or object as historical fact. As a consequence of this historicity, several texts of the timeless tradition can be dated; a historical comparison will be possible; and sometimes one can write the biographies of their authors.

In the followings, three contexts of Hamvas's opinions of tradition will be touched. At first, several parallelisms will be discussed in the history of ideas, focused on Karl Jaspers' theory on the axial age; and the need of the comparative research on Hamvas connected with other thinkers of the Central-European region, for example, Constantin Noica (1909-1987). After that, using the theory of the cultural memory of Jan Assmann, I will try to answer the following question; whether, it is possible to offer a description of the common specific features of Jaspers' canon of the masterpieces written in his "axial age", and that of Hamvas's sacred books, from the aspects of the inquires of the structure of the human communication, and cultural memory (Assmann 1992; 2011).

However, these text corpora sometimes have highly different writings; they are surprisingly similar in their structure, as wholes. At the end of my writing, I will analyse the features of Hamvas's ideas of tradition in praxis when he edits, translates and interprets concrete writing as a mediator of the ancestral tradition. It will be exemplified by a text, which offers a good opportunity to show the relationship of orality and literacy, problems of the application of the modern concept of authorship for the ancient times of bimediality, and the methods of cultural memory. It is the collection of the conversations and sayings of Confucius (Lunyu), usually entitled Analects in its English editions. Béla Hamvas translated and published the selected text of Lunyu, with his own introduction (Kungfutse 1943). It was based on a German version; by the evidence of his library, probably the version translated by Richard Wilhelm (Kungfutse 1921). Later, a re-selected text of Lunyu has become part of two text corpora of the sacred books, edited by him (Hamvas 2003; 1990). (In the followings, Chinese terms and names will be used in the standard pinyin transliteration, excluding the direct references to the bibliographic items with other forms of transliteration. The 
name of Confucius usually remained in the usual Latinised version, as an equivalent of the name form Master Kong.)

\section{Regional and European parallelisms of Hamvas's œuvre in the history of phi- losophy}

In the European culture, at least from the time of the Humanism and Reformation, there is a perpetual topic; we tend to suppose that we have lost our way; consequently we should find the point of an "original error, or sin", and rebuild the culture from the last level before it, based on the topic of the ancient myths of a golden age. Opinions of Nietzsche and Heidegger about this topic and their influence on Hamvas are wellknown. It is impossible to offer an interpretation of the loci of Hamvas's œuvre concerning the relationship of life and existence without a reference to the Heideggerian term of forgetting of Being (Seinvergessenheit). Nevertheless, we almost lack the comparisons with the thinkers of the same generation and the same region. It is enough to mention here the name of Constantin Noica, whose most famous twin-concept: becoming / being (Noica 2009), in the Romanian original devenire / fiinţă (Noica 1998) can be similar to Hamvas's concepts of life and existence. (The parallelism of the thoughts of Hamvas and Noica was thematised by Árpád Szakolczai, 2004.) It is an important task of the comparative intellectual history to find the reasons for the differences in their careers. However, Noica has been marginalised after World War II; he has remained part of the academic sphere and has become the master of the next generation of the Romanian philosophers. Hamvas had a fundamentally different role within the Hungarian culture. It is a task of the researches of the future to offer an analysis of the difference between the position of Hamvas, and almost all the other representatives of the traditionalism of his generation, who have been involved in the totalitarian ideologies, in the opposite of Hamvas's intellectual behaviour. This difference was significant in their intellectual orientation, as well; while the Romanian thinker had contact with the official philosophical life of Germany in the 1940s, Hamvas's German favourite was Karl Jaspers who lived in an internal emigration in the same years. The relationship of Hamvas with the Hungarian and international philosophical life of his epoch is not in the focus of the giant monography on Hamvas (for the discussed epoch see its $2^{\text {nd }}$ volume, entitled A Researcher of the Essence in Darabos 2002). An overview of the relationship between the philosophies of his age, among others, Jaspers, and focused on the discussed epoch; was offered by András Lengyel, with a reconstruction of the special position of a voluntary outsider, what had offered the possibility for Béla Hamvas the formulation his opinions within the academic sphere of philosophy, and as an opposition of the professional philosophy, (see Lengyel 2005). 
However, the connections between Jaspers and Hamvas are well-known, especially Hamvas's detailed analysis of the thought of the German philosopher, first published in 1941 (Hamvas 1988c), the parallelisms between Jaspers' concept of the axial age and Hamvas's ideas of the tradition were rarely touched in the scholar discourse. An overview of the afterlife of the Jaspersian idea, with parallelism with the thought of Béla Hamvas, was offered by Árpád Szakolczai (2004); who linked Béla Hamvas with the contemporary international discourse about the Axial Age, as well (Szakolczai 2005). Jaspers has formulated his theory of axial age in his abovementioned synthesis of the history of philosophy (Jaspers 1949; 1953); and Hamvas has started the research and analysis of the tradition earlier. Jaspers has described how he had developed the idea of the philosophy of world history connected with the world history of philosophy, and with the axial age in their centre, in his intellectual biography published at first in 1953 (Jaspers 1957; 1977); however, he has not used the term axial age concretely, in here. The new topic of his philosophy was caused by the influence of his readings about Chinese philosophy at the end of the thirties. According to Katalin Thiel, Hamvas has turned to the idea of ancestral tradition at the end of the thirties, after his great essay on the concept of the crisis published at first in 1937 (Hamvas 1983; Thiel 2002, 23. ff.). Consequently, the aim of comparison of the similar ideas of these authors is not to find an influence of Jaspers in Hamvas's thought, but an intellectual parallelism what is rooted in the features of their common, at least similar topic. By the formulation of Jaspers, in the $8^{\text {th }}-2^{\text {nd }}$ centuries B.C., especially in the middle of this period, in the $6^{\text {th }}$ century, the basic roots of the unitary culture of humankind have been established independently in China, India, and in the Western world. In the $20^{\text {th }}$ century when these historically separated cultures have been finally present for each other, it has become clear in the cultural praxis that the spiritual goods produced in different places in the axial age have referred to the common values of humankind, and they have established it historically, in the same time. There are significant similarities between Jaspers' list of the important works of the axial age and Hamvas's canon of the sacred books. A similar element of their interpretations is the central position of the common values of humankind, and their endeavour to recognise the non-European works as equal ones with the products of the Western thought, formulated by a style similar to the recent post-colonialist thought. Their common problem, rooted in the date of the axial age, is the evaluation of Christianity. However, the establishment of Christianity, especially the canonisation of the text corpus ("the Scriptures") is out of the extraordinary epoch when the most important books of the humankind have must been written by their interpretation, they did not want to neglect the Christian tradition. (The relationship of Hamvas, a son of a Lutheran pastor with Christianity was problematic thorough the whole of his œuvre.) In the same time, 
there are differences between their views, as well. Jaspers' axial age is a new, preparatory period of the world history for the future unity of the humankind; the same epoch in Hamvas's thought is a sign of deep crisis. These sacred writings refer to the ancestral tradition of the time before the crisis, what is available for us just in fragmented form, as writings instead of praxis. Hamvas focuses on the prerequisites, Jaspers on the consequences in the analysis of the same turning point of world history. In the followings, we will focus on the common features of the pieces of almost the same canons of Jaspers and Hamvas.

Béla Hamvas's sacred books and Karl Jaspers' Axial Age in the mirror of the concept of the cultural memory formulated by Jan Assmann

Jan Assmann's theory of cultural memory can be useful for us in the interpretation because its aim is to offer a description of the process of the tradition in the orality and literacy as the tool of the creation and maintenance of the collective identity. Assmann is a participant of the contemporary discourse on the Axial Age, as well. In his writings on this topic, he clarifies the parallelisms and differences between the ideas of Jaspers and his disciples, and his own theory (e.g. Assmann 2005; 2012). However, the subtitle of his masterpiece, Writing, Remembrance, and Political Imagination refers to political identity, case studies at the end of volume about the investigation of state, religion; history and science have an overview of the possible foundations of the collective identity and the schemes of the possible world-views. However, Assmann's examples are based on his Egyptologist background; and his first aim is to reconstruct the genesis of the Western thought, consequently, his work lacks the emphasis on the equality of the non-European cultures what is an important element both of the utterances of Jaspers and Hamvas. Assmann uses cultural paralelisms of the East to demonstrate that his theory describes the general laws of the cultural memory, not its special Western methods, only. Concerning the concept of the canon he mainly touches the same phenomena that are described by Jaspers as the works written in the Axial Age for the establishment of the common culture of the humankind, and by Hamvas as the saving of the timeless ancestral tradition in written form in the same epoch as the most ancient form of this tradition available for us. Assmann's keywords are the ritual and textual coherences. He regards the turn from the former to the latter one, the dominance of the later over the former one as the development of the new historical form of the cultural memory. After this turn, several texts of the flow of tradition what saved many elements of the orality have been marked, canonised; the canonised texts have formed a closed text corpus linked with the importance of the textual identity, in the end, the sacralisation process of the canonised text corpus. Political and religious communities based on these canonised and sacralised texts 
represent a new type of collective identity; however, they are a historically developed form of the communities based on the ritual coherence.

There is ambivalence toward the partly oral cultural material of the ritual coherence in the intention of the texts separated from the flow of tradition for creating a canon of the same tradition. Persons regarded as authors make modest statements that they do not say any new teaching but the whole ancestral tradition, without additions; it is the legitimation of the text after the model of the witness' oath that she or he will say the whole truth, and the truth, only. The aspect of time of the creators of the canon is double. Authors can see the temporality of their age and their works; they know that the text recorded by them could be recorded by other means; maybe they can see concretely that concurrent scribes record the same text in another form. They can have dubieties about the intentions of their audience, readings of later epochs and the survival of the text itself, but the tradition what must be recorded by them is selfidentical and timeless for them. Scribes often formulate their task is to record excellently particular texts (prayers, ritual texts, works of historiography, or epics) because their meaning has become unclear and the legitimacy of their different versions has become contested, because of the decline of collective memory.

In philosophy, the ambivalence toward writing has emerged in a characteristic, well-known form in Plato's works. Assmann's above referred work is based in its important loci on previous interpretations of Plato based on the theory and history of communication; amongst them, the most famous is the work of Havelock (1963). Hamvas's ideas on the writing are formulated in the clearest form in his interpretations of Plato, as well. In his most characteristic writing in this genre is an article entitled Platonism of the writing (Hamvas 2001). By Hamvas's interpretation, writing is a sign of the cultural decline, and its main sin is the canonisation, consequently, impoverishment of the original meaning. The only right for the existence of writing is its usage against the oblivion of the authentic existence and the ancestral tradition of the golden age, after the model of Plato, who was familiar both with the ritual coherence of the orality, and with the textual coherence, but he prefers the values of the former one. By Hamvas, Plato is conscious that his preferences concerning the archaic structure of the cultural memory imply the archaic view of the political community as it was formulated in the title of his article written by the opportunity of the publication of the first complete translation of Plato's œuvre in Hungarian, in 1943 (Hamvas 1988a). By the interpretation of Katalin Thiel, his ambivalence toward the ideas of time linked with the ancestral tradition has emerged in the clearest form in his interpretation of the Greek culture detailed in his Hexacymium (Thiel 2002, 99 - 100; Hamvas 1993, 327 -333). By Hamvas, it is a possible escape from the temporality and to reach the existence as eternity by a vertical way. Greeks could see the time both in a vertical 
and a horizontal way; we modern humans have lost this ability after the Greek epoch, in a concrete period of the history, consequently its recovery has a double way, a vertical one for the individual existence, and a historical, horizontal reconstruction as a doctrine for the public. A few years later, an ambivalent interpretation of writing has emerged independently from the Greeks as a general idea, within his ideas about the ancestral tradition (Hamvas 1988b, 63 - 64).

\section{Béla Hamvas as a creator of the corpus of the sacred texts: Confucius' case}

However, individuals as unrepeatable persons reach always the experience of the existence by vertical way, throw a conversion; Hamvas who was a librarian, a guard of the written heritage, and a critic of the literacy of an "age of decline" in his large written œuvre, in the same time, as an author had to reach the golden age partly by the interpretation of concrete, historically created texts offering a help for others by his writings to find and realise the ancestral tradition of the golden age. During his investigations about the essentially unwritten ancestral tradition, Hamvas has produced a whale of writings, and only writings; he has explained the priority of the pictorial thinking above the verbal one in written form, without any iconic illustration, as well. Hamvas could answer my critical note that it just seemingly a contradiction caused by the essence of our age, called by his term Apocalypse; his task is to try to write the unwritten ancestral tradition like Plato in a previous epoch. However, Hamvas has always criticised the process of canonisation in any culture, in his writing practice he has developed a great plan of canonisation in his Anthologia Humana, and in The Great Hall of the Ancestors; his aim was to edit a unified collection of all the sacred texts of the human culture as the saved fragments of the ancestral tradition in his translation and interpretation. In the followings, I will show how it is work in practice, exemplified by a work of Confucius with the translation and interpretation of Hamvas.

Confucius' conversations and sayings (Lunyu, Analects) is a paradigmatic example of the problem of the relationship between a thinker and a text attributed to him, in the turn of the orality and literacy, at the beginning of the process of canonisation by the Assmannian meaning of this term. Master Kong has written books, but they are not regarded as his philosophical works. By the Chinese tradition the official chronicle of his homeland, Principality Lu, entitled Springs and Autumns of Principality Lu (Spring and Autumn Annals, Chunqiu), and the edition of the Shijing were written by him. The latter one is a collection of the ritual songs known in his age; the edition is actually a canonisation process of a diffuse store of the oral texts in a fixed, selected, written form. However, these books are not attributed to Confucius by the modern sinology; it is symptomatic that what kinds of texts were attributed to him by the tradition of the classic Chinese culture. He was a master of the school of the future 
elite, but the curriculum of his school is not identical with his doctrine in narrow meaning. In Confucius' time, the usual subjects were the followings: ritual studies, music, writing, archery, chariot-driving, mathematics (including the astronomy). Master Kong has focussed on the first three subjects; it was usually the program of the winter semester in the similar Chinese elite schools. What is called Confucian writings both in the vocabulary of the Chinese tradition and the modern sinology, was written by the later generations of his disciples after the death of the last ones who had personal memories about him and his teachings. By the testimony of Lunyu, the subjects of his critical thinking were usually not the theses of other philosophers, but symbolic acts of the rulers in the sphere of power. For example, it is the appearance of a group of dancers in eight line, wearing special ritual dresses and ancient ritual bronze axes (Lunju III, 1), or the playing of a song (Lunyu III, 2) called Yung-ode (Shijing 282), in the rituals of the clans (jia) of the local aristocracy. Both the dance and the ode were originally parts of the representation of the imperial court usurped by the local aristocracy in Confucius' lifetime when the role of the Zhou-dynasty has become the representation of mere symbolic power. The usual answer of Master Kong in similar cases is a quotation of the actual locus of the Shijing with a short commentary demonstrating that the rite was managed in a wrong form and it will cause wrong consequences in Tianxia (the sphere under the Heavens).

At the beginning of the conversation we know just single information; that the Yung-ode was played in the ritual of the "three families". Confucius' quotes the actual locus of the Yung-ode for his disciples: "The princess assisting, / While the Son of Heaven looks profound.", and he adds: "what can be derived from it in the hall of the three families?" His textual quotation has made clear that the ritual is the privilege of the emperor, and his comment defines the (false) ritual context of the quoted verse; an imperial ritual was realised in the hall (ancestral shrine) of persons who are subjects of the emperor.

It is characteristic that Confucianism is the single Chinese philosophical school what was named not after its founder master, or after its central topic like in the cases of all the other schools. The Chinese name of the Confucian school is rujia, an individual Confucian called $r u$ what originally meant specialist of the rituals. The term $r u$ is prior than Confucianism itself. Originally, it referred to the group of specialists who were familiar both in the management of the rituals in practice, and in the conservation, and interpretation of the texts of rituals. They were on the margin of the ritual and textual coherences as a transition from the role of the memory specialists of the oral communities and the scribes or literati of the civilisations of literacy. In here the interpretation is more difficult because the group of specialists called $r u$ is part of a larger group of specialists called shi. Its versions in Western languages are usually 
connected with the world of literacy what is right for the later periods of the Confucianism and the Chinese culture, but it can be the root of misunderstandings in the earlier periods and in the time of the foundation of the school. Both $r u$ and shi have similar translated versions in the Western languages, usually scholars or literati. The early Confucians were not focused on the ritual texts, but on the right ritual practices by an auxiliary function of the interpretations of texts. By Confucius' opinions the general method for the reestablishment of the previous, legitimate state is the rectification of names (zhengming), made by (morally) noble men (junzi); after this act all the names of the ranks of the social life will refer their original functions what they had in the court of the idealised Zhou-dynasty. It can be reached by this method that the rituals $(l i)$ can work by the ritual music (yo), in a country unified by the rituals, without written law, and avoid the chaos (luan).

However, in Hamvas's interpretation of the program of the rectification of names saves its central position in the Confucian doctrine, the locus of Lunyu as the point of reference of this program is the part of Hamvas's collection of extracts entitled Anthologia Humana, as well; it has not linked with the spheres of the literacy, orality, and the rule, it remains a moral advise for the right behaviour. The most interesting is the special interpretation of the terms $l i$ and luan. However, the later one is not mentioned in Hamvas's interpretation as a term, it is clear from the loci of the text selected by him, and from their context that his ideas refer to this word of the original text. The term $l i$ has referred in its first meaning the principle of the right rituals, the correctly realised offerings and rites; Master Kong has used it for the right form of the court etiquette, and generally for the right form of the human behaviour. In the ancient Chinese thought, it can be associated with its homonym (tian)li, '(heavenly) order, (heavenly) schema', or with its other homonym $l i$ 'utility'. In the former case, the right human behaviour can be derived from the heavenly order; in the latter one, the relationship between human duties and utilities can be expressed. In the vocabulary of Master Kong the term $l i$ '(right) ritual, (right) human behaviour' is a rule of the civilised Chinese world what is unreachable for the barbarians. Its semantic field can be sown in the European culture if we translated it as nomos, however, this Greek term does not refer to rituals. By other way, with the Confucian thinkers of the later generations, we can say that $l i$ is the dao of the society.

In the interpretation of Hamvas the term li means cosmic law; it is an equivalent of the Greek logos. By Hamvas, Master Kong's works and life represent this li, and avoids Tianxia (the sphere under the Heavens) to fall in luan what is interpreted by Hamvas as the Greek chaos, far from the Confucian political meaning of this term. By Hamvas, however, Master Kong represents the timeless ancestral tradition without words, by the demonstration of right acts, only; but he has founded the unwritten 
ancestral tradition in ancient sacred texts and not in the survived fragments of the ancestral orthopraxis. (By the testimony of Lunyu, Confucius has not focused extremely on the sacred books in his thinking. For example, he has respected the old people because they can remember the orthopraxis of their youth before the luan.) However, Master Kong is a representative of a timeless knowledge, his supposed lifetime is not neutral for Hamvas; it must be within a marked epoch of the human culture. Master Kong must be "a contemporary of Laozi, Buddha, the last Zarathustra, Heraclitus and Pythagoras" who have had experiences about the beginning of the greatest crisis of the history of humankind independently, in different geographical places (Hamvas 2003, 11).

\section{Conclusion}

The result of Béla Hamvas's program for the canonisation of the ancestral tradition is a specially canonised, consequently uniformized and Hellenised Confucius. In this aspect, Hamvas was a son of his epoch; his interpretation developed in the 1940s has fitted to the line of the historiography of the Chinese philosophy emerged in the interwar period. In this time a significant textual knowledge about the classic Chinese literacy has accumulated, and the Chinese and European sinologists have tended to rescue the Chinese philosophy from the Hegelian scheme of the prehistory of philosophy, finding and creating ancient Greek-Chinese philosophical parallelisms. (For a characteristic, influential example of this kind of historiography of the Chinese philosophy, see Fung 1952 - 1953. For an overview of the above detailed Confucius-problems from the point of view of the contemporary Hungarian Sinology, see Mester 2017.) However, this aspect is a consequence of the common opinions in the sinology of his epoch, defeat of the program was predictable not only in the case of Confucius. The canonisation of the unwritten tradition in writing is probably impossible in general; and the presupposition of the original unity of the tradition can cause that an author of this presupposition would want to demonstrate this unity exemplified by any cultural phenomena, within any circumstances.

Assmann expresses his opinion that the idea of the Axial Age is rather a myth for him, and not a theory, by the title of his recent writing (Assmann 2012). He regards the danger of mystification that by the inherent enforced temporal and essential parallelisms, several important figures will absent from the list of the founders of world religions (for example Akhenaten, Moses, Jesus and Mohamed), and in the same time the multicolour and locally different tradition will be homogeneous in the interpretations; every culture will show the same for us. Assmann summarised his opinions by the followings: "As a result of these considerations concerning literacy as an agent of change in the structure and organisation of cultural memory, I have to confess that 
I cannot bring myself to really believe in the »Axial Age« as a global turn in universal history occurring grosso modo in the middle of the first millennium BCE. On the other hand, I find the concept of axiality (with pre- and post-axiality) a valuable and even indispensable analytic tool in the comparative study of cultures" (Assmann 2012, 398).

The real merit of Hamvas's intellectual endeavour is not hidden in his failed experiment of the demonstration of the unity of the ancestral tradition, by my interpretation. His greatest idea was an early conjecture of the significance of the turn of the cultural memory from the ritual to the textual coherence with important consequences for the structure of the collective identity. (Of course, my interpretation concerns Hamvas's central research program for the reconstruction of the ancestral tradition. I did not touch other genres of his œuvre here, for example, his novels and his writings about the fine arts.) However, the significance of his ouvre in the above outlined frame is more modest than it is mirrored in the cult developed around his person; it is a role not to be despised in the history of the European culture, with all its ambivalences.

\section{Bibliography}

ASSMANN, J. (1992): Das kulturelle Gedächtnis. Schrift, Erinnerung und politische Identität in frühen Hochkulturen. München: Beck.

ASSMANN, J. (2005): Axial "Breakthroughs" and Semantic "Relocations" in Ancient Egypt and Israel. In: J. P. Arnason - Sh. N. Eisenstadt - Bj. Wittrock (eds.): Axial Civilisations and World History. Boston - Leiden: Brill, 133 - 156.

ASSMANN, J. (2011): Cultural Memory and Early civilization. Writing, Remembrance, and Political Imagination. Cambridge - New York: Cambridge University Press.

ASSMANN, J. (2012): Cultural Memory and the Myth of the Axial Age. In: R. N. Bellah - H. Joas (eds.): The Axial Age and Its Consequences. Cambridge/MA - London: The Belknap Press of Harvard University Press.

DARABOS, P. (2002): Hamvas Béla. Egy életmü fiziognómiája. Vol. 1 - 3. Budapest: Hamvas Intézet.

FUNG, Y-L. (1952 - 1953): A History of Chinese Philosophy. Translated by D. Bodde. Vol. 1 - 2. Princeton/NJ: Princeton University Press.

HAMVAS, B. (1983): A világválság. Budapest: Magvető.

HAMVAS, B. (1988a): Az archaikus közösség. A teljes Magyar Platón megjelenése alkalmából. In: Béla Hamvas: Közös életrend. Budapest: FSZEK, 157 - 169.

HAMVAS, B. (1988): Scientia Sacra. Az öskori emberiség szellemi hagyománya. Budapest: Magvető.

HAMVAS, B. (1988c): Szellem és egzisztencia. Karl Jaspers filozófiája. In: Béla Hamvas: Szellem és egzisztencia. Pécs: Pannónia Könyvek, $27-84$.

HAMVAS, B. (1993): A babérligetkönyv. Esszék (1932 - 1945). Hexakümion. Nagy illúziók alkonyán (1937). Szombathely: Életünk Könyvek.

HAMVAS B. (2001): Az írás platonizmusa. In: Béla Hamvas: A láthatatlan történet (1943). Sziget (esszék) (1935-1936). Szentendre: Medio, $281-294$.

HAMVAS, B. (2003): Kongfu-ce: Lun-jü. In: Béla Hamvas: Az ösök nagy csarnoka II. Kína-TibetJapán. Szentendre: Medio, $9-29$.

HAVELOCK, E. A. (1963): Preface to Plato. Cambridge/MA: Harvard University Press. 
JASPERS, K. (1949): Vom Ursprung und Ziel der Geschichte. München: Piper.

JASPERS, K. (1953): The Origin and Goal of History. Transl. Michael Bullock. New Haven/CT: Yale University Press.

JASPERS, K. (1957): Philosophical Autobiography. Transl. Paul Arthur Schilpp, Ludwig B. Lefebre. In: P. A. Schilpp (ed.) The Philosophy of Karl Jaspers. New York: Tudor Publishing Company. $3-94$.

JASPERS, K. (1977): Philosophische Autobiographie. München: Piper.

KUNGFUTSE (1921): Gespräche. Transl. notes Richard Wilhelm. Jena: Diederichs.

KUNGFUTSE (1943): Lun Yü. Kung mester beszélgetései. Transl. foreword Béla Hamvas. Budapest: Bibliotheca.

LENGYEL, A. (2005): „,... szólj, Szokratész, van értelme még?” Forrás, 37 (10), 87 - 100.

MESTER, B. (2017): A hagyomány áramlása és az idő tengelye. Párhuzamok Karl Jaspers, Jan Assmann és Hamvas Béla gondolkodásában. Liget, 30 (11), 47 - 73.

NOICA, C. (1998): Devenirea întru fiinţă. Încercare asupra filosofiei tradiţionale. Tratat de ontologie Scrisori despre logica lui Hermes. Bucureşti: Humanitas.

NOICA, C. (2009): Becoming within Being. Transl. Alistair Ian Blyth. Milwaukee/WI: Marquette University Press.

SZAKOLCZAI, Á. (2004): Az axiális kor avagy a globalizáció új megvilágításban. Szociológiai Szemle, 14 (1), $36-65$.

SZAKOLCZAI, Á. (2005): Between Tradition and Christianity. The Axial Age int he Perspective of Béla Hamvas. In: J. P. Arnason - Sh. N. Eisenstadt - Bj. Wittrock (eds.): Axial Civilisations and World History. Boston - Leiden: Brill, 107 - 121.

THIEL, K. (2002): Maszkjáték. Hamvas Béla Kierkegaard és Nietzsche tükrében. Veszprém: Veszprémi Humán Tudományokért Alapítvány.

Béla Mester

Research Centre of Humanities, Institute of Philosophy

Tóth Kálmán u. 4

1097 Budapest

Hungary

e-mail: Mester.Bela@btk.mta.hu

ORCID ID: https://orcid.org/0000-0001-8504-638X 